\title{
Prens Sabahaddin Düşüncesinin Türk Sosyal ve Siyasal Düşünce Tarihindeki Temsiliyeti: Liberalizm mi? Muhafazakârlık mı?*
}

Öz

\author{
Dr. Öğr. Üyesi İlyas Sucu \\ Ondokuz Mayıs Üniversitesi Fen-Edebiyat Fakültesi \\ Sosyoloji Bölümü \\ İlyas.sucu@omu.edu.tr
}

Prens Sabahaddin ülkemizde sosyolojinin ilk ve önemli kurucularındandır. Onun İlm-i Icçtima'sı, Ziya Gökalp'ın İçtimaiyat'ı ile birlikte Türk sosyolojinde iki ana akım sosyoloji ekolünden biri olagelmiştir. Prens Sabahaddin ismi sosyolojinin yanı sıra aynı zamanda Türk siyasetinin de önemli isimlerinden biri olarak bilinmektedir. 1902'deki I. Jöntürk Kongresi'yle başlayan merkeziyetçiler ve adem-i merkeziyetçiler ayrımından bu yana, Prens Sabahaddin Türk siyasal düşünce hayatında liberal bir düşünce geleneğinin öncülerinden kabul edilmektedir. Merkeziyetçi/otoriter iktidar biçimleriyle olan siyasi mücadelesi göz önüne alındığında liberalizm içerisinde değerlendirilebilecek olan Prens Sabahaddin düşüncesi, müntesibi olduğu 'Sosyal Bilim' Ekolü'nün fikriyatı ile birlikte ele alındığında ise belirgin olarak muhafazakâr öğeler barındırmaktadır. Prens Sabahaddin'in 'Sosyal Bilim' anlayışının bizzat ideolojileri dışlayan tutumuna karşın, onun hem liberalizmin hem de muhafazakâr ideolojinin kimi öğretilerini ülkenin düşünce sistemine bilinçsizce de olsa taşıdığı ve bu bağlamda her iki ideoloji içerisinde de konumlandırılabileceği düşünülebilir.

Anahtar Kelimeler: Liberalizm, muhafazakârlık, Sosyal Bilim Ekolü, adem-i merkeziyet, teşebbüs-ü şahsi.

\section{Representation of Prince Sabahaddin's Ideas in Turkish Social and Political Thought: Liberalism or Conservatism?}

\begin{abstract}
Prince Sabahaddin is one of the first and most important founders of sociology in our country. His İlm-i İçtima has become one of the two mainstream sociology schools in Turkish Sociology with Ziya Gökalp's İçtimaiyat. Prens Sabahaddin's name is known as one of the important names of Turkish policy as well as sociology. After the separation of centralists and centrists which began with the $1^{\text {st }}$ Jöntürk Congress in 1902, Prens Sabahaddin was considered as one of the forerunners of liberal thought in Turkish political thought. While Prince Sabahaddin thought can be judged in liberalism in view of the political struggle with centralist/authoritarian forms of power, it has also considerably conservative elements when considered together with the idea of the 'Science Social' school of thought. In spite of Prince Sabahaddin's concept of "social science" that excludes ideologies itself, it can be thought that it unconsciously carried some teachings of both liberalism and conservative ideology in the system of thought of the country, and can be positioned in both ideologies in this context.
\end{abstract}

Keywords: Liberalism, conservatism, Science Social School, decentralization, private enterprise.

\footnotetext{
" Bu makale, Prof. Dr. H. Bayram Kaçmazoğlu danışmanlığında tamamlanan Türk Sosyoloji Tarihinde 'Sosyal Bilim' Ekolü başlıklı Doktora tezinden üretilmiştir. 


\section{GİRIŞ}

Prens Sabahaddin ülkemizde Türk sosyolojisinin olduğu kadar Türk siyasetinin de önemli isimlerinden biri olmuştur. Onu Türk siyasetinde bu kadar önemli kılan husus ise Prens Sabahaddin isminin, Türkiye'de liberalizmin öncüsü olarak genel kabul görmesidir. $\mathrm{Bu}$ makalede tartışmak istediğimiz ise tam olarak budur: Prens Sabahaddin iddia edildiği gibi Türkiye'de liberalizmin öncüsü müdür? Ya da karşıt görüşte olanların iddia ettikleri gibi tam aksine muhafazakâr düşüncenin mi temsilcisidir? Ayrıca Prens Sabahaddin kendi siyaset ve toplum tasavvurunu nasıl tanımlamıştır? Ya da onun sosyolojisini bir siyasal ideoloji altında ele almak, bir ideoloji şemsiyesi altına yerleştirmek mümkün müdür?

Prens Sabahaddin'in bir mektubunda (Ege 1977: 338) kendi düşüncesini dönemin tüm söylemlerinden uzak, bilimsel bir çerçeve içinde tanıttığını biliyoruz: "İşte muhafazakârlık, liberallik, demokratlik, sosyalistlik, teceddüt veya milliyetçilik gibi nazariyeler, hep ilmi tahlil yokluğundan veya zihinlere yerleşmiş bazı kanaatleri birer esash hakikat sayarak, onlardan istidlal yoluyla hükümler çıkarmak yanlış usulünden ileri geliyor. Fakat içtimai meselelerin İlm-i içtima ile tahliline girişilince açıça görülüyor ki bütün bu etiketler, bu basmakalı ünvanlar, hakikat halde hiçbir şey ifade etmiyor". Bağlı bulunduğu 'Sosyal Bilim' (Science Social) Ekolü'nün bilimsel yönteminin tüm bu ideolojilerin üstünde konumlandırıldığı bu düşüncede Prens Sabahaddin, açıkça kendi sosyal/siyasal düşüncesine bir çerçeve çizilmesini kabul etmemiştir. Sadece Prens Sabahaddin değil Prens Sabahaddin'in sosyolojide takip ettiği Fransa menşeli 'Sosyal Bilim' Ekolü'nün kurucusu Frederic Le Play ve devamcıları olan düşünürler de, kendilerini, liberal ya da bir başka ideolojiyle tanımlamamışlar, aksine siyasi ideolojilerin bilimsel derinlikten yoksun ve öznel olduklarını düşündüklerinden, pozitivist bilgi kuramlarının etkisiyle kendilerini herhangi bir ideoloji ile bağdaştırmaktan çekinmişlerdir (Özavcı 2011: 143). Yine de bir siyaset ve toplum tipi tercihi ve savunusu olan 'Sosyal Bilim' Ekolü'nün ve Prens Sabahaddin'in düşünceleri, siyasal bir çerçeve içinde ele alınmıştır.

Bu makalede Prens Sabahaddin'in öğretisi, onun sosyolojik görüşleri ve siyasal faaliyetleri üzerinden değil ${ }^{1}$, bizatihi liberalizm ve muhafazakârlık ideolojileri çerçevesinden ele alınacaktır. Bu ele alışta öncelikle Prens Sabahaddin'in fikri kaynaklarına odaklanılacak, Le Play ile devamcıları olan 'Sosyal Bilim' Okulu düşünürlerinin (Henri de Tourville, Edmond Demolins, Paul Descamps vd.) bu ideolojik kamplaşmadaki yerleri tespit edilecektir. İkinci olarak ise Prens Sabahaddin'in fikri kaynaklarından hareketle edindiği düşüncelerini, ülkenin sosyal ve siyasal düşünce bağlamına nasıl taşıdığı ve daha da önemlisi öğretisinin liberal ya da muhafazakâr nitelemesini hak edecek hangi iddia ve argümanlar taşıdığı tespit edilmeye çalışılacaktır.

\section{Prens Sabahaddin'in Düşün Kaynakları Üzerine Bazı Tespitler}

Prens Sabahaddin, ülkemizde genel kanı olarak liberalizmin taşıyıcısı ve savunucusu olarak görülmektedir. Acaba Prens Sabahaddin'e yakıştırılan bu liberal sıfat, kendisinin düşün kaynakları olan Le Play ve 'Sosyal Bilim' Okulu düşünürleri² için de söylenebilir mi?

\footnotetext{
1 Prens Sabahaddin'in sosyolojisi ve siyasal faaliyetleri çerçevesinde birçok çalışma mevcut olduğu için bu çalışmada benzer muhtevalı bir bölüme ihtiyaç duyulmamıştır. Konu ile ilgili olarak Türk Sosyoloji Tarihinde 'Sosyal Bilim' Ekolü başlıklı yayımlanmamış doktora tezimize bakılabilir.

2 'Sosyal Bilim' Ekolü'nün kurucusu olan Frederic Le Play ile kendisinin takipçileri olan ve Sosyal Bilim Okulu diye adlandırdığımız ve içerisinde Henri de Tourville ve Edmond Demolins'in yer aldığı düşünürler arasındaki kimi düşünce farklılıklarının sağlıklı bir şekilde ayırdına varmak için metinde böyle bir ayırıma gidilmiştir.
} 
Burada, bu konu ile ilgili mevcut tartışmalar ele alınarak hem Prens Sabahaddin'in düşün kaynaklarının hangi ideolojiden beslendikleri, hem Le Play ve ardıllarının farklılığı, hem de bir bütün olarak 'Sosyal Bilim' düşüncesinin savunuculuğunu üstlendiği sınıf ve değerler belirlenmeye çalışılacaktır.

Ekolün kurucu ismi Frederic Le Play, 19. yüzyılda Fransa'da meydana gelen toplumsal devrimler döngüsüne bir son vermek ve toplumu bir düzene kavuşturmak isteyen ve bunu da bilimsel bir temelde ele alan bir mühendis ve sosyologdur. Daha da ön plan çıkan özelliği ise sosyal reformcu kimliğidir. Dönemin en önemli sorunu olan işçi sorunu ve çözümü üzerine çalışan Le Play, geliştirdiği monografi tekniği ile özellikle dirlikli işçi ailelerinin özelliklerini belirleyerek hem işçi ailesini kayıtlamış ve yeni düzenin sahiplerine ve savunucularına problemin çözümü için işçi ailelerinin denetimi olanağını sunmuş; hem de dirlikli iş̧̧i ailelerini ön plana çıkararak problemin nedeni olarak gördüğü kararsız ailelere, yani bir düzeni ve dirliği olmayan işçi ailelerine yol göstermiştir. Fakat Le Play her ne kadar "sürüyü, yani iş̧̧i sınıfın şer kuvvetlerine, yani sosyalizme kaptırmak istemeyen" 3 bir düşünür olsa da o, toplumun bu bunalımından sanayileşmeyi, kapitalist endüstriyi sorumlu tutmuştur. Ona göre kapitalist endüstri ile birlikte eski düzen ve toplumsal bağll1ıklar ortadan kalkmış, toplumsal otoriteler kaybolmuştur. Yeni düzenle birlikte işçi problemleri, toplumsal bunalım halini almış ve siyasi istikrarsızlık baş göstermiştir.

Le Play tüm bu olanlar karşısında Fransa'da toplumu kontrol altında tutmak için aile merkezli bir anlayışla düzenin sürdürülmesini istemiştir. Eski düzenin değerlerinin, kurumlarının, sosyal yapısının muhafazasından yana olan Le Play, değişimi/yeni düzeni rasyonalist bakış açısıyla kaçınılmaz gören fakat toplumsal özellik ve değerlerin aniden değil, peyderpey, yavaş yavaş değişmesini arzulayan bir muhafazakârdır. İngiliz evrimci düşüncesi de Le Play'in bu tavrını desteklediğinden dolayı, yani devrimci değişime karşı evrimci bir anlayış getirdiğinden dolayı, Le Play'in Anglo-Sakson övgüsü daha iyi anlaşılabilir (Kaçmazoğlu 2012: 163). Bu temel felsefeden ve reformist bir tutumdan hareket eden Le Play, hem alternatifsiz olduğunu gördügü yeni düzenin devamını sağlayacak hem de eski düzenin kurumlarını ve değerlerini sürdürecek bir sentez gerçekleştirir. Bunu da aile üzerinden yapmak ister. Le Play'in Avrupa Isşçleri adlı eseri bunun en bariz örneğidir. Burada Le Play, ataerkil otorite ile bireysel özgürlük arasında bir denge bulmaya çabalamıştır. Tüm bu çabaları ve bu çabasına yol gösteren ilkeler göz önüne alındığında Le Play'in liberal düşünceden ziyade muhafazakâr ideolojiye yakınlığı açıkça görülecektir.

"Muhafazakârllğın sosyolog havarisi" olarak tanımlanan Robert Nisbet'e göre gerçek bilimsel sosyoloji alanında, alan verilerinin tespitinde, tasnifinde ve tümdengelimtümevarımcı kullanımında Auguste Comte'dan daha büyük bir kişi olarak Le Play, kendini muhafazakârlara adamış bir sosyologdur. Le Play'i "kral taraftarl, Katolik ve aileye, özellikle de orta gruptan ayrilamayan kök tipi bir aileye derinden bağgl $l$ " olarak tanımlayan Nisbet, ayrıca Sainte-Beuve'nin, Le Play'i "yeni doğmuş bir Bonald", "ilerlemeci" ve "bilimsel" olarak nitelemesini ise yerinde bir tespit olarak değerlendirmiştir (Nispet 2007: 143).

Bir başka eserinde (2002: 121-122) yine Le Play'in muhafazakârlığından kuşku duyulamayacağını belirten Nisbet, Le Play'in çok sayıda okur bulan dev eseri Avrupa İş̧ileri'nin sonuçlarından oluşan yapıtı Fransa'da Sosyal Reform'un, sosyolojik bir klasik kadar

${ }^{3}$ Trrnak içi ifade Cemil Meriç'ten iktibas edilmiştir.

SEFAD, 2018 (40): 253-266 
muhafazakâr olduğunu iddia etmiştir. Ona göre Le Play'in önerilerinde, Bonald'in daha önceki önerilerindeki gibi, kuvvetli özerk bir kilise; istikrarlı, köklü bir aile; boşanmanın kaldırılması; belirgin bir yönetsel adem-i merkeziyetçilik; yerellik ile feodalizmin bir birleşimi; merkezi siyasal iktidarın tüm toplumsal örgütlenme alanlarından geri çekilmesi; ekonomik, toplumsal ve kültürel alanlarda ferdiyetçiliğin en aza indirilmesi üzerinde sıkı sıkıya durulmaktadır. Ayrıca Ortaçağ hayranlığı konusunda seleflerinden daha ilerde olduğunu söylediği Le Play'in hakiki feodalizm ile onun monarşik antik rejimi altındaki yozlaşmış hali arasında bir ayrım yaptığını da ekler. Açıkça görüleceği üzere Le Play, Fransız Devrimi sonrası muhafazakâr düşüncenin önemli isimlerindendir. Onu diğerlerinden farklı kılan ise hem düşüncelerini bilimsel bir zemin üzerinde ele almasıdır hem de İngiliz toplum ve siyaset hayranlığ ve önerisidir. Fransız jakobenlerinin devrimle birlikte sadece bir siyasal rejimi değil onu çağrıştıracak her şeyi ama her şeyi yıkma girişimleri, tarih/gelenek saldırganlıkları; fakat buna karşın İngiliz toplumunda görece muhafazakârlarla liberallerin ortaklığı, bu toplum tipini Le Play nazarında dikkate değer kılmış görünmektedir.

Yine E. Healy (1947: 110)'in belirttiğine göre Le Play, birçok sosyoloji disiplinine kaynaklık etmesine rağmen Amerikalı sosyologlar tarafından onun yöntem ve tekniğinin yine onun referansıyla kullanılıp kullanılamayacağı tartışılmış ve çok az Amerikalı sosyolog tarafından kullanılmıştır. Bunun nedeni ise ona göre Le Play'in düşün sisteminde; liberal bir ekonomiden ziyade hamiliğin olması, bireysellikten ziyade dayanışmanın, materyalden ziyade maneviyatın üstünlügü, tarihin konjonktürel yorumlanması, sosyal reform olarak sosyal bilimlere normatif yaklaşılması, şehir hayatının birçok ahlaksızlığın sebebi olarak gösterilmesi, özellikle de kültüre karşı ailenin toplumun temel taşı olarak görülmesi ve bilgeliğin üstün olması gibi Fransız ve muhafazakâr bir bakış açısına sıkı sıkıya bağlı kalması gibi öğelerin yer almış olmasıdır. Sayılan tüm bu nedenlerden dolayı Le Play kesinlikle bir liberal olarak tanımlanamaz; fakat hem kendisinin İngiliz evrimci düşüncesine yakınlığından ve İngiliz toplum/siyaset hayranlığından hem de kendisinin içinde yer aldığı muhafazakâr düşüncenin, liberal düşünceyle özellikle özel mülkiyet ve devletin ekonomiye müdahale etmemesi fikirlerinde ortak bir anlayışın savunusu içindeymiş gibi algılanmalarından dolayı, yanlış bazı yorumlara da rastlamak mümkün olmuştur. Benzer yorumlara 'Sosyal Bilim' Okulu düşünürleri ve Prens Sabahaddin için de rastlanmaktadır.

'Sosyal Bilim' Okulu düşünürleri (Le Play devamcıları), Le Play'den farklı olarak aileyi değil bireyi merkeze alan bir anlayışa sahiplerdir. Le Play'in aile sınıflandırmasını detaylandıran okul düşünürleri, Le Play'deki gibi ailenin devamını sağlayan çocuğun değil, aileden ayrılan ve bir daha dönmeyen, kendi kişisel çabalarıyla hayatla mücadele eden çocuğun övgüsünü yapmışlardır. 'Sosyal Bilim' Okulu'nun bireyci ailesi, Le Play'in kök ailesine benzetilebilir fakat bireyci ailelerin dayanak noktaları kök ailede olduğu gibi aile değil kendileri olan, kendi işlerinin bağımsızca altından kalkabilen bireylerdir. Evin konumu da burada farklılaşır. Le Play'de ev ahlaki bir merkezdir, geleneksel/otoriter bir eğitimin verildiği yerdir. Çocukların dini eğitiminin dahi baba tarafından verildiği bu evde baba, Tanrıdan sonra itaat edilecek ikinci otoritedir. Aslolan itaat ve mülkiyetin devamıdır. Bu açıdan evin maddi bir merkezilik konumu da vardır. 'Sosyal Bilim' Okulu'nda ise ev, çocukların kişisel girişkenlik üzerine eğitim aldıkları bir merkezdir. Ev burada yine ahlaki bir merkezdir fakat bu defa maddiyattan sıyrılmış, geleneksel aile kurumu ilişkilerinden arınmış, sadece bireyci bir felsefeyle çocukların eğitildikleri bir konumdadır. Le Play ve 'Sosyal Bilim' Okulu arasındaki en büyük farklıllklardan biri budur (Rousiers-Rogers 1894: 
128-154.). Bu farklılığa rağmen 'Sosyal Bilim' Okulu düşünürlerinde de Anglo-Sakson övgüsü barizdir. Le Play, Anglo-Saksonların muhafazakâr ve otoriter/özel mülkiyetçi özelliklerini kendi tezi için ön plana çıarırken 'Sosyal Bilim' Okulu ise Anglo-Saksonların hususiyetçi yapılarını, kişisel girişkenliğe dayalı ev ve eğitim anlayışlarını ve merkez dışı yönetim anlayışlarını ön plana çıkarır.

Burada iki yargı üzerinde duracağız ve bunları temellendirmeye çalışacağız: İlki, Le Play düşüncesinin muhafazakâr ideoloji, 'Sosyal Bilim' Okulu'nun liberal ideoloji içerisinde sınıflandırılabileceğidir. İkincisi ise hem Le Play hem de 'Sosyal Bilim' Okulu'nun kimi farklılıklarına rağmen her ikisinin de muhafazakâr ideoloji içerisinde yer aldığıdır.

Le Play'in düşüncesinin muhafazakârlığ 1 ile ilgili bir ihtilaf söz konusu değildir. Le Play, 19. yüzyılın ikinci yarısında Avrupa'da muhafazakâr ideolojiyi canlandırmaya çalışan bir düşünür olarak tanımlanır. Aydınlanma karşıtıdır, temel tasası toplumu kapitalist modernliğin olumsuz etkilerine karşı korumaktır. Fakat bunu bilimsel-ilerlemeci bir anlayış içerisinde yapmaya çalışması, Le Play'i muhafazakâr düşünürlerden farklılaştırmıştır (Durukan 2009: 143-155). Çünkü Le Play'in deneysel araştırmaya bağlılığı, onu muhafazakârlar tarafından kabul edilemeyecek bulgulara götürmüştür. Le Play, toplumun uzun vadedeki refahını, o toplumu oluşturan ailelerin ekonomik güçlerine bağlar. Bu sayede bireyler arası dayanışmanın arttığını ve ayakta kalabilen elitlerin, çevrelerindeki işçi ve köylülerin sorunlarıla da ilgilendiğini belirten Le Play, sanayi devriminin getirdiği sosyal değişimin yakın bir tanığı olarak, kapitalizmin rasyonel ve hedonistik bireyciliğini ise reddeder. Onun temel savunusu ise toplumsal hiyerarşi ile istikrardır. Eserlerinde Edmund Burke, Louis de Bonald gibi muhafazakâr isimlerden alıntılar yapan Le Play, bu düşünürler gibi grubun bireyden önce geldiği ve toplumun bireyler toplamı değil kendi başına bir gerçeklik olduğunu savunur. Yine hızlı endüstrileşme ve merkezileşmenin yıkıcı etkilerine karşı, toplumsal dokunun birleştirici unsuru olarak dini değil, kök aileden gelecek ahlak anlayışını savunmuştur (Özavcı 2007: 237). Görüleceği gibi her ne kadar Le Play düşüncesinde muhafazakâr fikirlere karşı bir takım düşünceler (bilimse bir yöntem kullanması, bilimsel olmayan bulguları kabul etmeme, mülkiyetin geçişi konusunda farklılık, sanayileşmeyi topyekûn reddetmemesi, ilerlemeye inanması vb.) olsa da Le Play, muhafazakâr ideolojiyi canlandırmaya çalışan bir düşünürdür.

Diğer yandan 'Sosyal Bilim' Okulu birinci yargıya göre değerlendirildiğinde liberal bir öğretiye sahiptir. Çünkü okulun en temel görüşüne göre birey, aileden üstündür ve hatta birey devlet karşısında da üstündür. Bu durumun en bariz görüldüğü yerler ise İngilizce konuşulan ülkelerle İskandinavya'dır. Okulun aileden ziyade bireyi öne çıarmasının sebeplerinden biri, yine işçiler ile işçi sorunlarıdır. Le Play bu sorunu aileyi merkeze alarak ve eski düzenin değerlerini sürdürerek çözmek istemişti. 'Sosyal Bilim' Okulu'nda Le Play'in düşüncesi değiş̧ikliğe uğrar. Artık işçiler değişimden korunmak yerine bizzat değişime entegre edilmek istenmektedir. Özavcı (2007: 247)'nın okulun düşünürlerinden Paul de Rousiers'ten aktardığına göre işçilerin ahlaki, ekonomik ve siyasal gelişimleri bu okul düşünürlerine göre bir zorunluluktur. Rousiers, İngiltere'de işçilerin gelişimi için dört aracın varlığından söz etmiş bu dört aracı da; "ticaret ve sanayinin geliştirilmesi, işverenlerin şahsi girişimlerinin teşvik edilmesi, devlet müdahalesinin sinırlandırılması ve son olarak ta İngiliz karakterinin aşılanması" olarak saymıştır. Bu dört araç, günümüzde de liberal öğretinin araçları olarak karşımızdadır.

SEFAD, 2018 (40): 253-266 
Burada 'Sosyal Bilim' Okulu düşünürlerinin evi algılayışlarındaki farklılıklar ile çocuk eğitiminin dayanak noktasının gelenekten bireye, aileden kişisel bağımsızlığa, mülkiyetin korunmasından bağımsız mülkiyetler kurmaya kadar nasıl değiştirdikleri göz önüne alındığında Le Play-'Sosyal Bilim' farklılığı açıkça görülecektir. Ünlü eseri "Anglo-Saksonların Üstünlüklerinin Sebepleri Nelerdir?"de Demolins (Tarihsiz: 180-201), daha önce bir mülkiyet sahibi olmayıp da kişisel girişkenlikleri ile toplumsal hiyerarşinin üst basamaklarına hızla çıkan bireylerle ilgili birçok örnek verir.

Tartışma tam da bu noktada çıkar. Acaba Le Play gibi 'Sosyal Bilim' Okulu düşünürleri de muhafazakâr ideolojinin savunucuları mıdır; eski, yani feodal düzenin toplumsal yapısının sürdürülmesini isteyen bir düşün sistemine mi sahiplerdir? Kansu (2009a: 156-165)'ya göre bu sorunun cevabı evettir. O, özellikle okulun ve ülkemizde de Prens Sabahaddin'in toplum anlayışının temel kavramları olan adem-i merkeziyet ve teşebbüs$\ddot{u}$ şahsinin liberal bir toplumun savunusu için değil feodal bir toplumun savunusuna hizmet ettikleri görüşündedir. Kansu'ya göre özellikle Demolins ve Tourville'in ve 'Sosyal Bilim' çevresinin önemli kavramlarından biri olan adem-i merkeziyetle kastettikleri, esasen 1789 Devrimi öncesi Fransa'da var olduğu iddia edilen siyasal ve sosyal düzendir. Onlar açısından adem-i merkeziyetçilik, yüceltilmiş bir feodal düzeni temsil eder. Feodal düzende var olan siyasal, sosyal ve ekonomik yapı parçalanmış bir haldedir; aristokrasi ise toprakları üzerinde her türlü tasarrufa sahip olarak geleneksel devletin kontrol mekanizması dışındadır. Dolayısıyla bu toplumsal yapı, adem-i merkeziyetçi bir yapıdır ve bu yapıda aristokrasi, devlet ile tebaa arasında bir uzlaşma aracı ve mutlakıyetçiliği dengeleyen bir unsurdur. Tourville (2013: 165-194)'in daha sonra kitaplaştırdı̆̆ La Science Sociale dergisindeki makaleleri incelendiğinde bu durum daha çok netlik kazanabilir. Çünkü, Anglo-Sakson tipi toplumun hayali soy kütüğünün anlatıldığı bu makalelerde Tourville, özellikle feodal döneme yoğunlaşmakta ve bu dönemi kişisel özgürlüklerin en fazla olduğu dönem olarak nitelendirmektedir. İngiltere övgüsü de buradan ileri gelmektedir. İngiltere 19. yüzyılda bir taraftan modernleşmiş bir toplum ve endüstrileşmede en önde olan ülke iken diğer taraftan da eski düzeni tamamen ortadan kaldırmamış bir ülke olarak görülmektedir. Burada aristokrasinin hem ekonomik ve sosyal, hem de siyasal hayatta hâlâ belirleyici bir rol oynadığı görülür.

'Sosyal Bilim' Okulu'nun bireyci ailenin bayraktarlığını yaptığını belirtmiştik. Bireyci aile ise Le Play'in kök ailesinden evi terk edip, kendisine yeni hayat alanları açan bireyleri tanımlıyordu. İște Kansu (2009a: 161), okulun, özelikle de Demolins'in, 19. yüzyılın sonunda aristokratlara, kendilerine yeni yaşam alanları yaratmalarını ve sömürgelere yerleşerek Fransa'ya bu yolla hizmet etmelerini önermektedir. Yani Kansu'ya göre liberal bir öğeymiş gibi görünen bireyci aileden kasit budur. Kansu, gerek Le Play gerekse de 'Sosyal Bilim' Okulu düşünürlerinin bahsettikleri ikinci ana kavram olan özel girişimciliğin ise yalnızca aristokratlar elindeki büyük toprak işletmeciliğini kapsadığını iddia eder. Ona göre hem ticaret hayatı hem de gelişmiş fabrika üretimi, varolan ve toprağa dayalı hiyerarşik yapıyı kapitalist ilişkileri yaygınlaştırarak bozduğu için, bu düşünürlerce kötülenmiştir.

Özavcı (2007: 254-256) ise 'Sosyal Bilim' Okulu düşünürleri ile ilgili olarak söylenen bu aşırı-muhafazakâr nitelendirmeye karşı olarak, bu tanımlamanın Le Play için kısmen söylenebilse de okul için söylenemeyeceğini ifade eder. Ona göre 'Sosyal Bilim' Okulu'nun sorunsalı toplumun üretkenliğiyken, sanayi ekonomisinden rahatsızlık duymaları çelişik bir görüntü olacaktır. Ayrıca Demolins ve Tourville'in öğretileri kapitalist düzenle ön plana 
çıkan bir tür bireyciliğe vurgu yapmaktadır. Yani Le Play'deki aile vurgusu, yerini bireye bırakmıştır. Yine Le Play'de görülen kapitalist sistemin geleneksel anlayışa göre yapılanması, yerini anlayışın yeni sosyal düzene göre yeniden ele alınmasına bırakmıştır. Özavcı'ya göre 'Sosyal Bilim' Okulu'nun hedefi ve yöntemi, 1789 Devrimi öncesi var olduğu iddia edilen sosyal ve siyasal düzene geri dönüş değil; toplumsal değişimin yönüne paralel, yeni düzen içinde Amerika ve İngiltere' de örnekleri görülen, kendi değerlerine hâkim olarak yükselmeyi başarmış bireyler yetiştirecek bir organizasyon sağlamaktır. Yani doktrin bilimsel bir metottan hareket ederek, kapitalizme adaptasyonu hizlandıracak bir formülasyon peşindedir.

'Sosyal Bilim' Ekolü'nün bir bütün olarak -gerek Le Play'in gerekse de 'Sosyal Bilim' Okulu düşünürlerinin- elitist bir tutum sergilemiş olmaları, ekolün muhafazakâr eğilimini güçlendiren bir diğer öğe olarak düşünülebilir. Le Play'in sosyolojisinde önemli kavram ve olgulardan biri otoritedir. Le Play, toplumsal kargaşa içindeki Fransa'nın bu durumdan kurtulması için Tanrı'ya ve baba otoritesine bağlılığı önermektedir. Hatta baba, çocuklarının dini eğitimlerinden sorumludur. Le Play, bu hususun kilisenin değil, babanın sorumluluğunda olduğunu düşünmektedir. Evdeki otoritenin iş hayatındaki eş değeri ise işverendir. Le Play, muhafazakâr bir düşün sisteminin savunuculuğunu üstlendiğinden, kapitalist yeni düzendeki işverenin rolünün de feodal dönemdeki aristokratın rolü gibi olmasını ister. Zaten Le Play, özelde Fransa genelde de Avrupa'nın içinde olduğu toplumsal buhranın bir nedeni olarak da toplumdaki elitlerin görevlerini yerine getirmemeleri olduğu görüşündedir. Geleneksel, yani feodal dönemde bireyin bağlılıkları vardır. Bunlar dini bağl1lıklar ve dünyevi bağl1lıklardır. Tanrıya, kiliseye bağlılık dini bağlılıktır, bir soyluya bağlılık ise dünyevi bir bağlılıktır. Yeni düzen her iki bağlılık türünü de yok edince, toplumsal bunalımlar da kaçınılmaz olmuştur Le Play'e göre. İşte Le Play'in bilimsel bir zemin üzerinde yapmaya çabaladığı sosyal reform da, bireyin bağll1ıklarını yeni düzen çerçevesinde yeniden oluşturmaktır. Ancak bu sayede toplumsal bunalımlara bir son verilebilir.

Le Play feodal düzenin ve ataerkil aile yapılanmasının devamını dilese de günün koşullarında bunun mümkün olmadığını görmüş ve yeni düzenin sahiplerine toplumsal değişim/dönüşümün daha yavaş ilerlemesi ve bu değişim/dönüşümün toplumsal bunalımlara yol açmadan nasıl atlatılacağı hususunda çözümler önermiştir. Onun temel düşüncesi devrimci bir toplum anlayışından ziyade eski düzenin sahiplerini ve dini de ihmal etmeyecek fakat yeni düzenin de varlığını ve gelişmesini sarsmayacak bir düşüncedir. $\mathrm{Bu}$ ise İngiliz evrimciliği düşüncesinden başka bir şey değildir. Dolayısıyla Le Play, evde babanın işte ise işverenin otoritesini sağlamak, bireylerin ise toplumsal sorumluluklar alacak bir tarzda yetiştirilmelerini istemektedir. Yani Le Play düşüncesinde toplumsal problemlerin üstesinden öncelikle, ülkedeki elitlerin, gelişen yeni sosyal ve ekonomik düzen karşısında ayakta durabilecek şekilde eğitilmeleri ve onların diğer sınıfların sorunlarını gözetmeleri ile gelinebilir. Demolins (Tarihsiz: 195)'e göre bu husus, yani elitlerin toplumsal sorumluluk alacak tarzda yetiştirilmeleri ve bu sorumlulukları alarak diğer sınıfları gözetmeleri, aslında İngiltere ve Amerika'da elitler tarafından bilinçsiz bir şekilde yapılmaktadır. Fransa'nın yapması gereken ise bu örnekten hareketle ve bilimsel kaynakların yardımıyla bu işin bilinçli bir şekilde yapılmasıdır.

Le Play'den sonra ise ekolün bu elitist yönetim anlayışı daha çok görünür olmuştur. Bunlardan ilki şahsi teşebbüs fikridir. Okulun ve daha sonra Prens Sabahaddin'in de temel 
düşüncesinden birini oluşturacak bu şahsi teşebbüs fikri, özünde elitist bir motif taşır. Bu söylem ile hükümetin yerine, tarımsal bölgelerde geniş toprak sahiplerinden, sanayi bölgelerinde de sermaye sahipleri ve işverenlerden kendi refah ve gelişimleri kadar, onlarla çalışan işçi ve köylülerin de refah ve gelişimlerini gözetmeleri beklenmektedir. Bu elitlerin görevi, gözetimlerindeki gruplara hizmet etmek; onların sağlıkları, iş durumları ve sorunlarıyla da ilgilenmektir. Çünkü varlıklarını sürdürmeleri verdikleri hizmete bağlı olarak değişecektir (Özavcı 2007: 253). Bu bağlılık, yani işverenlerle işçinin yeni düzendeki bu bağlllı̆̆ı, Le Play'in önerdiği (Zimmerman 1964: 17-19) devaml-ihtiyari işçi-işveren münasebetini yansıtır. Bu sistem ise feodal sistem olan devamlı-mükellefiyetli sistem ile kapitalist sistemde olan geçici sistemin bir ara formülüdür.

İşte burada temel sorun bu elitlerin nasıl yetiştirileceği sorunudur. Le Play ve 'Sosyal Bilim' Okulu düşünürleri tüm çabalarını bu konu üzerinde yoğunlaştırmışlar ve monografilerle sorunu, yani Fransa'nın kararsız aile ile kamucu toplum yapısına sahip olduklarını tespit ettikten sonra çözüme odaklanmışlardır. Çözüm ise bireyci toplum örneğinin biricikliğini sergileyen Anglo-Sakson toplumların modelliğinde gerçekleşecektir. Şimdi yapılması gereken, Fransız bireylerini, bu sisteme göre eğitmektir. İşte Demolins'in Ecole des Roches'i (Kayalar Okulu) ${ }^{4}$, bu temel saiklerle kurulmuştur. Yani Demolins özelinde 'Sosyal Bilim' Okulu üyeleri, bir süre sonra dikkatlerini tahlilden eğitime çevirmişler ve yeni düzene entegre olacak bireyler yetiştirmeye önem vermişlerdir.

Sonuç olarak adem-i merkeziyetçi yönetim, laissez-faire, asgari devlet, kişisel girişkenlik gibi özellikler muhafazakâr ideolojinin olduğu kadar liberal ideolojinin de argümanlarıdır. Hatta liberal düşüncede merkezi ve güçlü devletle tekelci bir sermaye mantığı daha çok ön plandadır. Dolayısıyla şimdilerde liberal düşüncenin argümanları olarak okunan kimi özellikler aslında muhafazakâr bir düşün sisteminin temel yapı taşlarındandır. Bu bakış açısından Le Play kadar 'Sosyal Bilim' Okulu düşünürleri de muhafazakârlardır denilebilir. Fakat defaten denildiği gibi kimi ortak anlayış ve argümanlar, farklı yorumlara ve sinıflandırmalara neden olmaktadır. Burada bilinmesi gereken en önemli husus, okulun birey anlayışının liberal bir öğretiden beslenmediği, bilakis Le Play düşüncesinin ardılları tarafından açılımlanması, farklı yorumlanması sonucu ortaya çıktığı ve bu bireyci düşüncenin asıl kaynağının liberal öğreti değil İngiliz muhafazar/evrimci anlayışına dayandığıdır.

\section{Liberalizm-Muhafazakârlık Karşıtlığında Prens Sabahaddin}

Eğer liberalizmin evrensel, bir anlamıyla katı bir tanımından yola çıkılırsa, Prens Sabahaddin'i liberal olarak tanımlamak güçtür. Çünkü Prens Sabahaddin, Anglo-Sakson modelini, Demolins aracılı̆̆ıyla endirekt öğrenmiştir. Dolayısıyla Anglo-Sakson liberalizminin kurucuları olan John Locke, David Hume, Adam Smith, Jeremy Bentham ve John Stuart Mill5, onun eserlerinde kendine yer bulamamıştır (Durukan 2009: 154). Yine Prens Sabahaddin, düşünürlere olduğu gibi Batı'da yerleşik siyasal/sosyal teorilere de

\footnotetext{
${ }_{4}^{4}$ Demolins ekol içerisinde sadece teorik bir çabayla yetinmemiş, kamucu toplum yapısından bireyci toplum yapısına dönüştürmeyi amaçladığı Fransız toplumu için bir örnek eğitim kurumu da açmıştır: Ecole des Roches (Kayalar Okulu). Bu okul Demolins'in İngiltere ziyaretinde gezdiği ve hayran olduğu bazı İngiliz özel okullarının Fransız modelidir. Bu okullarda teorik eğitimin yanı sıra aynı zamanda birçok alanda el becerilerine dayalı uygulamalı eğitimler de verilmekte; öğrencilerin, zihinsel gelişimlerinin yanı sıra bedensel ve kişilik gelişimleri de dikkate alınmaktadır.

${ }^{5}$ Prens Sabahaddin'in tüm eserleri içerisinde sadece John Stuart Mill'in, o da sadece bir defa, Yedinci Mektup'ta ismi geçmiştir.
} 
kayıtsız kalmıştır. Endüstriyel üretim, işçi sınıfı, fabrika, sosyalizm gibi birçok mesele, Sabahaddin'in ilgi alanının dışında yer almışlardır. Diğer yandan liberalizm, kapitalizmin oluşumuyla ve kapitalist sistemin sürdürülmesiyle bağlantılı bir sistemdir. Bu açıdan liberalizm, bir burjuva ideolojisidir. Prens Sabahaddin'in görüşlerini ortaya koyduğu ilk dönem, yani II. Meşrutiyet öncesi düşünüldüğünde, imparatorluğun kapitalist bir evrede olduğu ya da bir ideolojiye kaynaklık edebilecek çapta bir burjuvanın varlığı söz konusu değildir. Bu durumda bir düşünce çizgisinin varlığı da beklenemez. Dolayısıyla liberalizmin kurucularıyla bir bağı olmayan Prens Sabahaddin'in, ülke içinde de liberalizme kaynaklık edecek bir toplumsal taban ${ }^{6}$ ve devralabileceği bir liberal düşünce geleneği de yoktur. ${ }^{7}$

Buna karşın liberalizmin daha gevşek bir tanımından yola çıkıldığında ya da "bir tek değil, tarihsel şartlar ve ulusal yörüngelerin etkisinde şekillenen birden fazla liberalizmin olduğu" görüşü kabul edildiğinde ise Prens Sabahaddin'i ve düşüncesini liberal olarak tanımlamak kolaylaşacaktır. "Liberalizm; kapitalist gelişim, ticaret ruhu ve güçlü bir burjuva anlayışının meyvesi olarak görüldüğünden bu üç öğenin yokluğunda liberalizm de olmayacaktır" görüşünün terk edildiği ve Batı dişı toplumların henüz kapitalist gelişmenin ilk aşamasındayken de liberal ideolojiyi kendi toplum şartlarına göre yaşayabildikleri (Özavcı 2011: 138) örneğinin sergilendiği bir dönemde, Prens Sabahaddin'in görüşlerini, liberalizm içinde ele almak zor olmamıştır.

Prens Sabahaddin'in -liberalizmin de en önemli argümanı olan- her türlü mutlakiyetçiliğe karşı oluşu, bireye verdiği özel önem, bireysel girişkenliği toplumsal gelişim için şart koşması, özel mülkiyeti desteklemesi ve siyasal iktidarın adem-i merkeziyetçi olması gerektiği düşüncesi ele alındığında, kendisinin neden ülkemizde liberal düşüncesinin savunucuları arasında sayıldığı anlaşılacaktır. Şükrü Hanioğlu (2011)'nun haklı bir tespitiyle, Türkiye'de liberal düşüncenin kökenlerinin liberal felsefeden ziyade otoriter ideolojiye karşı çıkma anlayışında aramak gerekir. Ona göre varlı̆̆ını sorgulamadan kabullendiğimiz liberal gelenek, aslında otoriter, tek tipçi, her alanda iyinin ne olduğuna karar verme tekelini elinde tutmak isteyen bir ideolojinin eleştirisinden başka bir şey değildir. Bu açıdan ülkemizde liberal düşüncenin bir geleneği ve felsefesi değil siyasal bir duruşu ve bu duruşun bir tarihinden bahsedilebilir. Prens Sabahaddin hem İttihat ve Terakki ile birlikte mutlakıyet rejimine hem de daha sonra İttihat ve Terakki'nin otoriter ve merkeziyetçi devlet anlayışına karşı bu duruşu sergilemiştir.

Burada açıklığa kavuşturulması gereken bazı hususlar vardır. Öncelikle Türk siyasal hayatında bir yorum geleneği olarak İttihat ve Terakki ile siyasi karşıtları -ki en bilineni Prens Sabahaddin'dir- arasında bir merkeziyetçi-adem-i merkeziyetçi karşıtlığında eşleştirilen liberal-anti liberal dikotomisi vardır. İttihat Terakki ile başlayan ve Cumhuriyet

\footnotetext{
${ }_{6}$ Prens Sabahaddin kurucusu olduğu Teşebbüs-ü Şahsi ve Adem-i Merkeziyet Cemiyeti'nin, örgütsel anlamda merkeziyetçiliğe karşı yerelciliğin, padişah ve kul-bürokratlarına karşı politik ve ekonomik talepleri yükselen eşrafayan, şeyh, tüccar, azınlık gibi çeşitli sosyal sınıfların etnik, siyasi ve sınıfsal çıkarlarını temsil ettiği yönünde güçlü bir kanı olmakla birlikte askeri okullarda da kabul görmesi, aslında hem İttihat ve Terakki Cemiyeti'nin hem de Teşebbüs-ü Şahsi ve Adem-i Merkeziyet Cemiyeti'nin tabanlarının çok net ayrışmadığının (Reyhan 2008: 21. 119) bir işareti olarak da okunabilir.

7 Tanzimat sonrası dönemde özellikle ekonomi alanında bazı liberal düşüncelerin tartışıldığı ve Namık Kemal, Ohannes Efendi ile Mehmet Cavit gibi isimlerin liberal düşünce alanındaki öncülükleri dillendirilebilir. Fakat 1860 sonrasına tekabül eden bu tartışmaların, Prens Sabahaddin için bir liberal gelenek oluşturması mümkün değildir. Kaldı ki ülkemizdeki kimi liberal yazınlar içinde Prens Sabahaddin adı anılmamaktadır. Örneğin Tevfik Çavdar'ın Türkiye'de Liberalizm (1860-1990) başlıklı eserinde Prens Sabahaddin ismi geçmemektedir.
}

SEFAD, 2018 (40): 253-266 
Halk Fırkası ile devam eden bu merkeziyetçi anlayışın karşısında ise Teşebbüs-ü Şahsi ve Adem-i Merkeziyet Cemiyeti ile başlayan, Ahrar Fırkası, Hürriyet ve İtilaf Fırkası, Terakkiperver Cumhuriyet Firkası, Serbest Fırka ve Demokrat Parti'yle devam eden bir liberal çizgiden bahsedilir. Bu karşıtlığın söylemlerini tartışmak niyetinde değiliz. Fakat bilinmesi gereken husus, 1908 'de Meşrutiyet'in ilanını sağlayan ve daha sonra I. Dünya Savaşı sonuna kadar imparatorluğu yöneten İttihatçı kadroların, ülkede, özelikle de ekonomi alanında ciddi bir liberal politika uyguladıklarının aşikar olduğudur. ${ }^{8}$ Sadece politik düzlemde değil liberal bir düşünce geleneğinin oluşmasına da kaynaklık eden İttihat ve Terakki iktidarı için, Mehmet Cavit Bey örneği tek başına yeterlidir. İttihat ve Terakki'nin İktisat Nazırı olan Cavit Bey, aynı zamanda Sakızlı Ohannes Efendi ve özellikle Ulum-u İktisadiye ve İçtimaiye Mecmuası yazarı Ahmet Şuayip'ten sonra en önemli liberal düşünürdür. ${ }^{9}$

O halde Prens Sabahaddin ve sosyolojisini ya da destek verdiği siyasal oluşumları İttihat ve Terakki karşısında liberal bir çizgiye oturtan hususiyet nedir? Öncelikle siyasal bir ayrışma, tabii olarak fikri bir karşıtlı̆̆ da beraberinde getirmiştir. İkinci olarak liberal felsefeden etkilenmek yerine Prens Sabahaddin'in İngiliz toplum/siyaset modeli hayranlığı, İngiliz liberalizminin bazı unsurlarını fark etmeden düşüncesinde yer vermesine yol açmıştır. Özellikle Özavcı (2011: 159)'nın belirttiği gibi Prens Sabahaddin'in liberalliğinin siyasal bir ideolojiyi kanıksamasından çok, onun ithal edilmiş birçok fikrinin bazı Viktorya dönemi liberallerinin liberalizm anlayışları ile örtüşmesine dayandığını ve Sabahaddin'in büyük ihtimalle bilinçsiz bir şekilde Ortodoks liberal anlatının bazı öğretilerini Türkiye bağlamına taşıdığını belirtmek gerekir. Sabahaddin'in İngilizlere, Anglo-Sakson toplumlara duyduğu hayranlığı liberalizme duyulan hayranlık gibi algılamak bizi, Prens Sabahaddin sosyolojisiyle birlikte tüm 'Sosyal Bilim' ekolü düşünürlerini ve Le Play'i, liberal felsefenin içinde değerlendirme yanlışlığına götürebilir. Üçüncüsü Prens Sabahaddin'in İttihat ve Terakki düşünürlerine göre daha çok halka güveniyor olmasıdır. İttihat ve Terakki düşünürleri sosyal köken itibariyle ne kadar halktan olsalar da, daima seçkinci bir tarafları olagelmiştir. Oysaki Prens Sabahaddin, mahalli seçimlerin bile İttihat ve Terakki'nin bazı düşünürlerince ifade edildiği gibi ehliyetsizlerin değil, namuslu ve yetenekli insanların seçilmesiyle sonuçlanacağına inanmaktadır. Bu açıdan Prens Sabahaddin'in düşüncesi, bir anlamda bireyi ön plana çıkardığı için daha halkçıdır. Çünkü siyasi olmayan bir elit düşüncesini dönem koşullarında sadece kendisi ve Abdullah Cevdet ileri sürmüşlerdir (Mardin 2008: 293, 299, 306). Dördüncü olarak Prens Sabahaddin, siyasal otoritenin denetiminin sadece anayasal ve parlamenter rejim ile değil, aynı zamanda toplumun bireyci

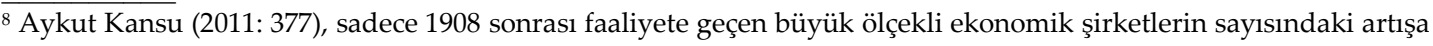
bakmanın bile 1908 devrimini bir burjuva devrimi olarak nitelendirmeye yeteceğini ifade etmiştir. Ayrıca Türkiye ekonomisinin 1908'le başlayan süreç içinde hızlı bir şekilde kapitalistleştiğini kabul etmemenin mümkün gözükmediğini ifade eden Kansu, kapitalist ekonominin yerleşmesi ve gelişmesi için yapılan tüm hukuki değişiklikler arasında 1909 yılında çıkarılan ve Türkiye'de grevi yasaklayan Tatil-i Eşgal Kanunu'nu örnek verir. Bu kanun, 1908 devriminin tam anlamıyla hangi sınıfların çıkarlarını koruyup kolladığı konusunda hiçbir şüpheye yer bırakmayacak kadar açık bir ipucu vermektedir. 1908 devrimini gerçekleştirenler özgürlük, eşitlik ve kardeşlikten bahsetmektedirler; fakat bu kavramların içi $1789^{\prime}$ dan beri mülklü sınıflar tarafından liberal düşünce geleneği çerçevesinde doldurulmuş kavramlardır.

${ }^{9}$ Bu konuyla ilgili olarak bakınız: Kansu, Aykut (2009b). "20. Yüzyıl Başı Türk Düşünce Hayatında Liberalizm”. Modern Türkiye'de Siyasi Düşünce Cilt 1: Cumhuriyete Devreden Düşünce Mirasi: Tanzimat ve Meşrutiyet'in Birikimi. ed. Mehmet Ö. Alkan. İstanbul: İletişim Yay. 277-295. Mehmet Cavit Bey'in 1899-1901 tarihleri arsında basılan dört ciltlik İlm-i İktisad kitabı, liberal ekonomik kuramın hem genel bir anlatımı hem de savunusu olarak kaleme alınmıştır.
} 
yapıya dönüştürülmesi ve hayatla mücadele etmeyi bilen, çalışkan, yeni bireylerin ortaya çıkması ile sağlanabileceğini belirtmiştir (Özavcı 2011: 159). Dördüncü maddeyle bağlantılı olarak beşincisi, Prens Sabahaddin'in meseleyi yalnızca bir rejim sorunu olarak değil bir toplumsal yapı meselesi olarak ele almasıdır. Dönem itibariyle tabuları yıkan memur eleştirisi de dikkate alındığında, toplumsal yapı değişikliği fikri, oldukça radikal bir söylemdir. Tüm bu söylenenlerle birlikte yeniden siyasetin belirleyiciliğine dönecek olursak; II. Meşrutiyet sonrası her iki karşıt akımın birleşme çabalarına ve imkânına rağmen siyaseten ayrışmaları ve muhalefette kalan Prens Sabahaddinciler ile daha sonra Ahrarcıların, hem toplumsal taban olarak İttihatçıların karşısında yer alanların ve dolayısıyla eşraf-ayan, azınlık ve eski düzen yanlılarının haklarını savunan bir merkeze dönüşmesi hem de söylem olarak İttihat ve Terakki'nin merkeziyetçi anlayışına karşı duruşları, kendilerini liberal olarak nitelemeye yetmiştir. ${ }^{10}$

Aynı şekilde Prens Sabahaddin'in görüş ve düşüncelerini muhafazakâr ideoloji içinde ele almak da fevkalade mümkündür. Yalnız burada dikkat edilmesi gereken husus, Prens Sabahaddin'in söylemlerini, düşünsel kaynakları ile birlikte ele almanın zorunluluğudur. Zira ancak bu şekilde Prens Sabahaddin'in düşüncelerinin muhafazakâr -hatta Katolik muhafazakâr-, karşı-devrimci bir anlaysştan beslendiği anlaşılabilir. ${ }^{11}$ Bu düşünsel kaynakların liberal ya da muhafazakâr, hangi felsefi anlayış ya da ideoloji altına yerleştirileceğini bir önceki başlıkta tartıştığımızdan, burada tekrardan ele almaktan kaçınıyoruz. Fakat burada Prens Sabahaddin'in düşünsel kaynaklarını ele alışı ve bunlardan nasıl bir siyasal/sosyal sistem devşirdiği ile ilgili birkaç hususa değinmek istiyoruz.

Mardin (2008: 293)'in belirttiği üzere, Prens Sabahaddin'in zaaflarından en önemlisi 'Sosyal Bilim' öğretisini siyasi plana aktarırken aceleci davranmış olması ve bu öğretinin bilimsel yöntem ve tekniğinin altında bir sosyal felsefesinin olduğunu görmemiş olmasıdır. Mardin'in "sosyal vicdam olan Katolikliğin doktrini" olarak tanımladığı bu öğretide aileye gösterilen saygı, ortaçağın iktisadi sisteminin saygısını içerirken, bireye duyulan saygı ise gücünü dini bir görüşten almaktadır. Prens Sabahaddin ise bu düşünce tarzının sadece yüzeyinde bulunan bir tekniği bizzat bir siyasi teori haline getirerek, kendini bu derin dini ve felsefi köklerden ayırmıştır. İkinci olarak; kamucu yapıdan bireyci yapıya geçişteki en önemli ve öncelikli aşama olan yönetimin adem-i merkezileştirilmesi, uygulama olanağına kavuştuğunda, toplumun feodaliteye kaymaması mümkün görülmemektedir. Bu projenin yerel beylere ve seçkinlere önemli ayrıcalıklar, özerklikler vermesi ise kaçınılmazdır (Kaçmazoğlu 2012: 167). Böylesi bir durumun yol açacağı siyasi buhran ise varlık ve bekâ endişesi taşıyan Osmanlı için yıkım demektir. Yine Prens Sabahaddin, ülkenin gelişmişlik düzeyiyle yönetimin adem-i merkeziyetçiliği arasında bir paralellik kurmuş ve sosyolojisini temellendirmiştir. Fakat her ikisi arasında her zaman doğrusal bir ilişki olmadığı gibi, Prens'in övgüsünü yaptığı İngiliz ve Amerikan toplumlarında zamanla merkezileşmenin $\operatorname{arttığ1~da~bir~gerçektir.~Sadece~bu~iki~toplum~tipinde~değil,~endüstriyel~gelişmeyle~}$ merkeziyetçilik arasında paralellik olduğu, günümüz dünyasında görüleceği üzere bariz bir şekilde ortadadır. Dolayısıyla Prens Sabahaddin'in sosyolojisini temellendirdiği yönetim şeklinin tarihsel akıbeti dönem itibariyle sorunlu görülmektedir.

\footnotetext{
${ }_{10}$ Burada Batı kaynakları ve basının da İttihat ve Terakki'ye yönelik muhalif grupları daima liberal olarak nitelediklerini unutmamak gerekir.

11 Bu konuyla ilgili olarak bakınız: Kansu, A. (2009). Prens Sabahaddin'in Düşünsel Kaynakları ve AşırıMuhafazakâr Düşüncenin İthali. Modern Türkiye'de Siyasi Düşünce Cilt 1: Cumhuriyete Devreden Düşünce Mirasi: Tanzimat ve Meşrutiyet'in Birikimi (Editör: Mehmet Ö. Alkan) içinde. İstanbul: İletişim Yayınları. ss. 156-165.
}

SEFAD, 2018 (40): 253-266 


\section{SONUÇ}

'Sosyal Bilim' Ekolü'nü ülkemize tanıtan ve ekolün düşüncelerinin ülkemizdeki ilk temsilciliğini üstlenen Prens Sabahaddin, savunusunu üstlendiği bu düşüncelerle sadece Türk sosyolojisini değil Türk siyasal düşüncesini de yakından etkilemiştir. Fakat Prens Sabahaddin'in ülkemizde liberal düşüncenin kökenlerinden biri olduğuna dair genel kabul karşısında bu çalışma sonucunda ulaştığımız netice olumsuzdur. Prens Sabahaddin'in liberal düşünceyle ilişkisi dolaylıdır ve ancak bilinçsiz bir şekilde liberal öğretinin bazı öğelerini ülke bağlamına taşıdığı görülmektedir. İngiliz siyaset ve toplum tipi hayranlığı ile birlikte düşünüldüğünde Prens Sabahaddin, İngiliz liberal düşüncesinin laissez faire, özel mülkiyet, adem-i merkeziyet, bireycilik vb. gibi bazı hususiyetlerini ülke bağlamına taşımıştır. Kaldı ki kendisi de hiçbir şekilde liberal nitelendirmesini kabul etmediği gibi ne liberalizmin klasik referanslarına ulaşmıştır ne de dönemin siyasal/sosyal teorileriyle ilgilenmiştir. Otoriter/totaliter rejimlere karşı mücadele eden kesimlerin liberal olarak nitelendirilmesi varsayımından hareketle, Prens Sabahaddin'e atfedilen liberal sıfatını, onun liberalizmin felsefi kökenlerine yaslanması dolayısıyla değil, otoriter olarak nitelediği bir rejime (II. Abdülhamid ve İttihat ve Terakki yönetimleri) karşı sergilediği bir duruşla kazandığı söylenebilir.

Düşün kaynakları dikkate alındığında ise Prens Sabahaddin'in liberalizmden ziyade muhafazakâr ideolojinin siyaset ve toplum tasavvuruna dair kimi görüşlerin savunusunu üstlendiği rahatlıkla iddia edilebilir. Fakat burada Prens Sabahaddin'in 'Sosyal Bilim' Ekolü'nün düşüncelerine derinlikli olarak nüfuz edemediği, Le Play ve Tourville'den ziyade sadece Demolins üzerinden bir okumayla ekole intisap ettiği görülmekte, dolayısıyla ekolün ancak popüler düşüncelerini (kamucu-bireyci toplum tipi ayırımı vb.) ülkenin düşünsel ve siyasal bağlamına taşıdığı görülmektedir. $\mathrm{Bu}$ ise muhafazakâr bir düşün sistemiyle çevrelenmiş olan ekolün birey anlayışı, dinin teorideki yeri, aile ve diğer geleneksel otoritelerin konumu gibi konuların Prens Sabahaddin'in fikriyatında bir yer edinememesiyle sonuçlanmıştır. Muhtemel ki, dönemin siyasi şartları içerisinde kendi siyasi konumunu güçlendirecek ve oldukça hızlı, kesin ve pratik sonuçları olacak bir siyasi program arayışı; Prens Sabahaddin'in bir bütün olarak ekolün ya da ekol temsilcilerinin ortaya koymuş oldukları ve 'Sosyal Bilim' anlayışlarının temelinde yer alan insan ve toplum felsefelerine odaklanmasını geçersiz kılmıştır. Dolayısıyla Prens Sabahaddin'in en büyük zaafı, 'Sosyal Bilim' öğretisini siyasi plana aktarırken aceleci davranması ve bu öğretinin bilimsel yöntem ve tekniğinin altında bir sosyal felsefesinin olduğunu görmemiş olmasıdır. Sonuç itibariyle Prens Sabahaddin, Türkiye'nin sosyal ve siyasal düşünce bağlamına hem liberal hem de muhafazakâr ideolojilerin kimi öğretilerini -bilinçsizce ve Prens Sabahaddin'in kendisi bu ideolojileri basmakalıp unvanlar olarak nitelendirmiş olsa da- taşımış görünmektedir. 


\section{SUMMARY}

Prince Sabahaddin had been one of the important figures of Turkish politics as well as Turkish sociology in our country. The reason of this importance in Turkish politics is that the name Prince Sabahaddin has been generally recognized in Turkey as the vanguard of liberalism in Turkey. But considering the sources of thought (Science Sociale School), it is seen that Prince Sabahaddin thought has a conservative tendency. Prince Sabahaddin's relationship with liberal thought is indirect and it is seen that he unconsciously carries some elements of liberal teaching to the context of the country. When Prince Sabahaddin is considered with his admiration to British political and social type, it can be seen that he carried some characteristics of British liberal thought such as laissez faire, private property, decentralization, individualism etc. to our country. Moreover, he himself had no access to the classical references of liberalism, nor to the political / social theories of the time, as he himself had no way accepted his liberal characterization. Based on the assumption that those who struggled against authoritarian / totalitarian regimes characterized him as liberal, it can be said that, Prince Sabahaddin earned this adjective liberal, not opposing to the philosophical roots of liberalism but against a regime that he described as authoritarian (the rulings of Abdülhamid II and İttihat ve Terakki).

Considering the sources of thought, it can easily be argued that Prince Sabahaddin took on the defence of conservative ideology on the concept of politics and society rather than liberalism. But here it can be seen that Prince Sabahaddin could not penetrate deeply into the thoughts of the 'Social Science School'. It is seen that instead of Le Play and Tourville, it only reads with a reading through Demolins. Therefore, it is seen that he carries only the school's popular thoughts (public-individualist type discrimination, etc.) to the intellectual and political context of the country. This resulted in the lack of a place in Prince Sabahaddin's idea, subjects such as the understanding of individual, the place of religion in theory, the position of family and other traditional authorities which is surrounded by a conservative system of thought. Possibly, seeking of a political program that is fast and practical which will strengthen his political situation has invalidated the focus of Prince Sabahaddin and his followers' philosophies based on human and society, underlying the 'Social Science' thought.

As a result, it can be considered that despite the attitude of Prince Sabahaddin in excluding the ideologies, he unconsciously carried some doctrines of both the liberalism and the conservative ideology into the country. 


\section{KAYNAKÇA}

Çavdar, Tevik (1992). Türkiye'de Liberalizm (1860-1990). Ankara: İmge Kitabevi.

Demolins, Edmund (Tarihsiz). Anglo-Saxonlarm Esbab-ı Faikiyeti Nedir? Anglo-Saksonlar Hakkında Tedkikat-ı İçtimaiye. çev. A. Fuad-A. Naci. İstanbul: Araks Matbaası.

Durukan, Kaan (2009). "Prens Sabahaddin ve İlm-i İçtima: Türk Liberalizminin Kökenleri". Modern Türkiye'de Siyasi Düşünce Cilt 1: Cumhuriyete Deoreden Düşünce Mirası: Tanzimat ve Meşrutiyet'in Birikimi. ed. Mehmet Ö. Alkan. İstanbul: İletişim Yay. 143-155.

Ege, N. Nurettin (1977). Prens Sabahattin: Hayatı ve İlmi Müdafaaları. İstanbul: Güneş Neşriyat.

Hanioğlu, M. Şükrü (23.01.2011). Hepimiz Liberal miyiz? Sabah Gazetesi. https://www.sabah.com.tr/yazarlar/hanioglu/2011/01/23/hepimiz_liberal_miyiz. [10.05.2018].

Healy, S. M. Edward (1947). "Le Play's Contribution to Sociology: His Method". The American Catholic Sociological Rewiew. 8 (2): 97-110.

Kaçmazoğlu, Hacı Bayram (2012). “Türkiye'de Science Sociale Ekolünü Temsil Etmek ya da Sosyoloji Üzerinden Anglo-Saxon Çıkarlarına Koşulmak: Prens Sabahattin". Sosyologca Dergisi. (3): 161-169.

Kansu, Aykut (2009a). "Prens Sabahattin'in Düşünsel Kaynakları ve Aşırı Muhafazakâr Düşüncenin İthali". Modern Türkiye'de Siyasi Düşünce Cilt 1: Cumhuriyete Devreden Düşünce Mirası: Tanzimat ve Meşrutiyet'in Birikimi. ed. Mehmet Ö. Alkan. İstanbul: İletişim Yay. 156-165.

Kansu, Aykut (2009b). 20. "Yüzyıl Başı Türk Düşünce Hayatında Liberalizm". Modern Türkiye'de Siyasi Düşünce Cilt 1: Cumhuriyete Devreden Düşünce Mirası: Tanzimat ve Meşrutiyet'in Birikimi. ed. Mehmet Ö. Alkan. İstanbul: İletişim Yay. 277-295.

Kansu, Aykut (2011). 1908 Devrimi. İstanbul: İletişim Yay.

Nispet, Robert (2002). Muhafazakârlık. Çev. Erol Mutlu. Sosyolojik Çözümlemenin Tarihi. ed. Tom Bottomore-Robert Nisbet. Ankara: Ayraç Yay. 93-127.

Nispet, Robert (2007). Muhafazakârllk: Düş ve Gerçek. Ankara: Kadim Yay.

Mardin, Şerif (2008). Jön Türklerin Siyasi Fikirleri. İstanbul: İletişim Yay.

Özavcı, H. Ozan (2007). "Prens Sabahaddin'in Fikri Kaynakları: Le Play ve Toplum Bilim”. Doğu Batı Dergisi. (41): 231-258.

Özavcl, H. Ozan (2011). “Düşünce Tarihi Merceğinden: Türkiye'de Liberalizm”. Doğu Batı Dergisi. (57): 137-174.

Reyhan, Cenk (2008). Türkiye'de Liberalizmin Kökenleri Prens Sabahaddin (1877-1948). Ankara: İmge Kitabevi.

Rousiers, Paul de.- Rogers, Corneila (1894). "La Science Sociale". Annals of the American Academy of Political and Social Science. (4): 128-154.

Sucu, İlyas (2014). Türk Sosyoloji Tarihinde 'Sosyal Bilim' Ekolü. Doktora Tezi. Malatya: İnönü Üniversitesi.

Tourville, Henry (2013). The Growth of Modern Nations. London: Forgotten Books.

Zimmerman, Carle (1964). Le Play ve Sosyal İlimler Metodolojisi. çev. Oğuz Arı. İstanbul: Fakülteler Matbaası. 